\title{
SWOT ANALYSIS ON MANAGEMENT INFORMATION SYSTEM OF UNIVERSITY OF DEBRECEN
}

\author{
A DEBRECENI EGYETEM VEZETÓI \\ INFORMÁCIÓS RENDSZERÉNEK SWOT \\ ELEMZÉSE
}

Tímea Gebei - Szilvia Vincze

VIR Központ, Kancellária, Debreceni Egyetem, Magyarország

\author{
Keywords: \\ higher education \\ management information system \\ University of Debrecen \\ SWOT analysis \\ decision support \\ Kulcsszavak: \\ felsőoktatás \\ vezetői információs rendszer \\ Debreceni Egyetem \\ SWOT elemzés \\ döntéstámogatás
}

\begin{abstract}
In 2009, an SAP-based management information system (MIS) has been implemented at University of Debrecen (UD). After the introduction of the system, in 2014, MIS Centre - the organisation responsible for operation - has been established. The MIS of UD operates functionally, however, it has wider range of uses and the opportunities offered by the system have not yet been fully exploited. In our paper, SWOT analysis was used to present the currently unused functions of MIS and based on the results, we propose suggestion for development.

\section{Összefoglalás}

A Debreceni Egyetemen 20o9-ben kezdődött meg egy SAP alapú vezetői információs rendszer (VIR) implementálása. 2014-ben, a bevezetést követöen létrejött a rendszer müködtetését biztosító szervezet, a VIR Központ. A DE VIR funkcionálisan müködik, azonban felhasználási köre és lehetöségeinek kiaknázása még nem teljes körü. A tanulmány SWOT elemzés segítségével mutatja be a VIR jelenleg kihasználatlan funkcióit és tesz javaslatot fejlesztésre.
\end{abstract}

\section{Introduction}

Over recent years, Hungarian higher education sector has undergone significant changes; besides the continuous decline in student numbers, university financing has also been going through a transformation. Despite this challenging environment, institutions have to maintain high quality educational and research activities, they should take part in both social and business life and they must accomplish their public service tasks.

These changes increasingly require the university management also to take decisions based on up-to-date and well-structured information. From 2009, management information 
systems have been implemented in several higher education institutions as a means of management decision support, especially with the purpose of measuring the achievement of institutional strategic objectives [2]. The implementation of an information system is a complex task affected by many factors and it poses a serious challenge for these institutions.

At University of Debrecen, an SAP-based data warehouse was launched in two development phases by channelling five source systems. Reports were produced for top management for measuring strategic targets and indicators determined in the Institute Development Plan and for middle management for measuring operative processes and supporting daily work. Leaders need data and information at all level of organisation hierarchy to be able to make decisions which increase performance. These information requirements are different at middle-level and top-level management. Different management levels are interested in different information at the same time. For operational work prompt, precise and quantifiable inside information, while for strategic decisions future-oriented, cumulative, relatively hardly quantifiable and mostly external information are required [1].

UD-MIS projects can be considered successful, the implementation of the system was done, and data were loaded from the five source systems which can be reported quickly and effectively due to the properly designed data models, saving time and energy for the people responsible on the source system side.

\section{Methodology}

\subsection{SWOT analysis}

SWOT analysis is a method enabling to examine the impacts of a newly introduced service and its proper interpretation can help the development.

The principle of the SWOT method is to determine strengths and weaknesses and reveal opportunities and threats of a given service, project, process, overall, the object of the analysis.

An important feature of SWOT that it shares the analysis: the first two fields - strengths and weaknesses - investigate the internal characteristics of the enterprise, while the second two fields - opportunities and threats - aim at analysing the environment surrounding the enterprise. Strengths and weaknesses are internal factors and thus they can be influenced, however, threats and opportunities mean external conditions that can be controlled only in rare cases, but there is no real chance to manage them. A strong rule of the method that a factor cannot be listed in two dimensions of the grid; we must decide which "side" of our subjectmatter is characterised by the factors [2]. Figure 1 presents a possible display of SWOT analysis.

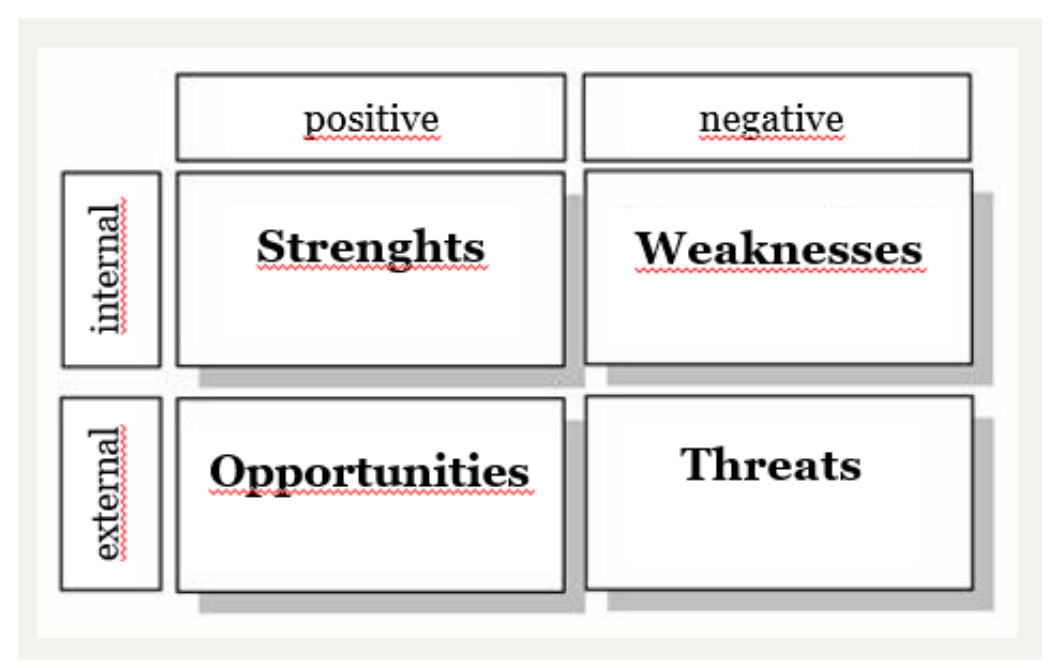

Figure 1 A possible display of SWOT analysis [5] 


\subsection{Conditions of the analysis}

The Senate of University of Debrecen established an autonomous organisation, MIS Centre, for the direct operation of the management information system implemented at University of Debrecen. Tasks of the MIS Centre shall include the following:

- Realisation of institutional strategy related to the Management Information System.

- Determination of professional contents in accordance with the MIS strategy, designing data set to be provided.

- Continuous supervision of data set to be provided in MIS.

- Monitoring the operation of subsystems, professional contact with persons responsible for the data content of subsystems.

- Defining further development path of the system.

- Organising information meetings for management and training for users.

- Support the Institute Development Plan, technical designing of the measurement of indicators undertaken in IDP, furthermore, producing reports as required for monitoring the achievement of institutional strategy [4].

SWOT analysis mainly builds on the experience gained through working procedures in MIS Centre and it is intended to explore the characteristics of internal and external environment of MIS at University of Debrecen and to what extent it supports the workflows on different levels.

\section{Results}

As a part of our analysis, a SWOT matrix has been created and it presents the factors by four aspects. Strengths and opportunities were virtually identified as the positive impacts of the management information systems. Weaknesses and threats mainly stem from the institutional operating specificities and the complexity of the system. Table 1 summarizes the SWOT matrix of UD MIS.

Table 1 SWOT matrix of UD MIS

\begin{tabular}{|l|l|}
\hline \multicolumn{1}{|c|}{ STRENGTHS } & \multicolumn{1}{c|}{ WEAKNESSES } \\
\hline $\begin{array}{l}\text { The system can provide data in sufficient time } \\
\text { and in appropriate structure according to } \\
\text { management requirements. }\end{array}$ & $\begin{array}{l}\text { Data purity of source systems is dubious; the } \\
\text { number of administrators of source systems is } \\
\text { particularly high. }\end{array}$ \\
\hline $\begin{array}{l}\text { It is suitable for preparing immediate reports } \\
\text { from source systems with daily data loading. }\end{array}$ & $\begin{array}{l}\text { Support of the system depends to a large extent } \\
\text { on the vocation of the management. }\end{array}$ \\
\hline Permanent availability is provided. & $\begin{array}{l}\text { Reports are inflexible, adapting to minor } \\
\text { changes in legislation is difficult. }\end{array}$ \\
\hline $\begin{array}{l}\text { Iterative data retrievals can be programmed } \\
\text { thus significant time saving can be achieved. }\end{array}$ & $\begin{array}{l}\text { Adaptation and development are very expensive } \\
\text { and time consuming. }\end{array}$ \\
\hline $\begin{array}{l}\text { Customized reports and statements can be } \\
\text { created for specific needs. }\end{array}$ & $\begin{array}{l}\text { Concerning further development and operation, } \\
\text { the institution is heavily dependent on service } \\
\text { providers since it lacks skilled people. }\end{array}$ \\
\hline $\begin{array}{l}\text { It has the accessory function of web reporting, } \\
\text { providing the management easy usage and } \\
\text { interpretation. }\end{array}$ & $\begin{array}{l}\text { Its use and operation require high level of } \\
\text { knowledge in SAP data warehouse. }\end{array}$ \\
\hline \multicolumn{2}{|l|}{ andandard data warehouse has been } \\
\hline
\end{tabular}




\begin{tabular}{|l|l|}
\hline \multicolumn{1}{|c|}{ OPPORTUNITIES } & \multicolumn{1}{|c|}{ THREATS } \\
\hline $\begin{array}{l}\text { It can play a controlling role regarding data } \\
\text { purity of source systems. }\end{array}$ & $\begin{array}{l}\text { Public sector leaders are still less motivated in } \\
\text { daily usage of MIS. }\end{array}$ \\
\hline $\begin{array}{l}\text { Scalable source systems enable the creation of } \\
\text { complex queries building on several source } \\
\text { systems. }\end{array}$ & $\begin{array}{l}\text { Operating and development costs are extremely } \\
\text { high. }\end{array}$ \\
\hline $\begin{array}{l}\text { Interconnection of information from different } \\
\text { processes and topics is provided due to } \\
\text { integrated operation, it can support } \\
\text { management decisions by creating } \\
\text { multidimensional data models. }\end{array}$ & $\begin{array}{l}\text { High degree of dependence on IT service } \\
\text { providers. }\end{array}$ \\
\hline $\begin{array}{l}\text { It may be adapted to plan budgets, compare } \\
\text { plan-fact data, and support controlling activity. }\end{array}$ & $\begin{array}{l}\text { Data loading from source systems are done } \\
\text { hanually and infrequently in certain cases and it } \\
\text { reports. }\end{array}$ \\
\hline $\begin{array}{l}\text { The system mative impact on the availability of MIS } \\
\text { data retrieval. }\end{array}$ & \\
\hline $\begin{array}{l}\text { It can be a base for monitable for fulfil any ad-hoc indicators of } \\
\text { teaching and research performance evaluation. }\end{array}$ & \\
\hline
\end{tabular}

\section{Discussion}

\subsection{Strengths}

Fast data providing and availability were identified among the strengths of UD MIS. However, this requires smooth operation of the system and data loading without any mistakes.

In order to specific and ad-hoc requests can be served by MIS, appropriately qualified workers are needed who proficient in MIS and source systems and who are able to recognise connections in the massive amounts of data sets and implement to prepare reports in the data warehouse.

Presenting statements is also one of the strengths, however, it presupposes that workers at MIS have the knowledge to present management reports and executive summaries in an expected way, moreover, leaders also need a certain level of proficiency in using web reporting interface.

\subsection{Weaknesses}

Data purity is one of the main weak points of MIS system since data in data warehouse and reports generated from them are as reliable as data of source systems. Source systems are utilised by many users who record data according to different principles and regulations and it imposes a burden on the MIS Centre to detect and standardize them.

Another difficulty is the complexity of the system. So as the workers can apply it, high level BW skills are needed on the on hand, and on the other hand data modelling and other operational procedures can be attained by professionals as well through long learning process. SAP typically offers such solutions for which it provides its own professionals on exceptional high price level which resulted a strong dependence on IT service providers.

Inflexibility of reports is generally arisen from their complexity since the more complex the topic is, the harder to adapt to the changes. Another reason for it the slow pace of information flow, because information about the modifications done in the source systems have to be known also by the operators of the data warehouse in order to set ups of MIS can be adapted to the source system.

\subsection{Opportunities}

Management information systems still have significant potential in terms of their uses; the number of their application fields is unlimited. It may contribute to measure the attainment 
of strategic objectives, compare of plan-fact data, perform controlling functions and quantify the teaching and research performance. Achieving this requires precise and coherent set of indicators and indicators must be clearly defined.

It may also be able to check the data purity of source systems since data from different source systems are interpreted together and examined in different ways in the data warehouse and it can highlight flawed processes or data management.

One of the biggest opportunities stems from the presentation of data from different source systems in one report as running separate queries is not necessary; instead data warehouse can solve it by a one-time reporting. An example could be the number of students per teacher which uses data from database of employees and database of students as well.

\subsection{Threats}

High cost is one of the greatest threats to the functioning of MIS regarding both the operation and possible improvements and this is closely linked to that weak point that the training of an in-house employee for this task is very costly and time consuming.

It is considered a threat as well if leaders cannot be motivated for MIS, the lack of support may call into question its presence. Indeed, MIS has been principally implemented with the purpose of supporting management decision, this system works to that end.

\section{Conclusions}

University of Debrecen is one of the biggest and most complex higher education institutions in Hungary with a functioning Management Information System. Tasks related to the operation of the system are performed by a special department named MIS Centre.

UD MIS is not flawed; many difficulties have to be overcome during its operation. Quality of data from source systems is not adequate in all cases and data loads are not always carried out regularly. Validating report is burdensome as well; the expected results can be hardly produced. To improve conditions, standardisation can be an important step, i.e. if administrators of source systems carry out data recording on the same principles. Regulating and recording of procedures may provide clear instructions for responsible persons on the source system side specifying the frequency and the data set to be transferred.

Because of the complexity of the system, UD is substantially dependent on the IT support which is excessively costly. There is still a lack of human resources at the institution with appropriate knowledge to fully carry out this function. To remedy this problem, a professional staff should be established who can resolve the operation of the system. A similar process has taken place at UD related to SAP ERP economic management system which is fully operated by the staff members of UD SAP Competence Centre who are own employees of the University. However, this is a long-lasting process; it is worth the effort to eliminate the dependence.

There are many possibilities for extending the data sets and channelling source systems. The basic and core activities are been covered yet with the linked data sets on teaching, research, financial affairs, projects, graduate tracking and human resources, however, there may be demand for reports on patient care or production activity. It is particularly true now, when Hospital of Gyula Kenézy is in the process of integration, and as a result, one of the largest healthcare units will be established.

Implementation of UD MIS supported by European Union resources is to improve the quality of higher education. The reform of higher education is a necessary action, institutions must adapt to the new expectations and they have to accept the fierce competitive situation being among universities.

Despite the initiative, the efficiency of database-based management information systems has not yet taken effect nor in public sector and therefore, neither in higher education. Resulting from the financing of higher education, the main function is still to fulfil public services, however, efforts have been initiated which show a demand for the autonomy of higher education institutions. In this connection, support and utilisation of management information systems are expected to change positively in the near future. 


\section{Bibliographical References}

[1] Babu, K.V.S.N. J. - Sekhar, B.M. R. (2012): MIS. Vs. DSS in Decision Making. In: Global Journal of Management and Business Research, 12 (16) pp. 1-9.

[2] Bálint, J. -Halász, G. (2011): Vezetői döntéshozatal és felsőoktatási menedzsment. In: AVIR Kézikönyv. (Bángi-Magyar, A. - Farkas, K. - Horváth, T. - Kiss, L. Ed.) Educatio Társadalmi Szolgáltató Nonprofit Kft., pp. 25-49.

[3] Chikán, A. (1997): Vállalatgazdaságtan. Aula Kiadó, Budapest

[4] Debreceni Egyetem (2015): Debreceni Egyetem Kancellária ügyrend.

[5] Hegedűs H. (2009): Projektmenedzsment I. [Online]. Available: http://centroszet.hu/tananyag/ projektmenedzsement/index.html. [Accessed: 12-May-2019]. 